\title{
MONITORING PROPOSAL OF THE SPECIES NEPTIS RIVULARIS (SCOPOLI, 1763) IN POLAND
}

Faculty of Animal Breeding, Bioengineering and Conservation, Warsaw University of Life Sciences - SGGW, Warszawa, Poland

\begin{abstract}
Hungarian Glider (Neptis rivularis), a species of butterfly of the family Nymphalidae, which in Poland is under partial species protection and is included in the Red list of threatened animals in Poland with the EN category. The occurrence and abundance of Neptis rivularis are strictly dependent on the presence of Spiraea salicifolia L., which is the host plant of the species. Limiting the range of the occurrence of the Neptis rivularis in Poland also results from the decline in the number of suitable habitats. This article presents a proposed methodology for monitoring based on the evaluation of indicators of population condition in the form of: number of adults, abundance index, number of caterpillars and population isolation, and indicators of habitat condition - presence of the Spiraea salicifolia and exposure to the sun of microhabitats. The concept of the population condition assessment methodology was based on non-invasive observation of adults and counting caterpillars. The concept of habitat condition assessment methodology is based on a strong relationship between the Neptis rivularis and the Spiraea salicifolia. It is proposed to annually monitor the Neptis rivularis population in at least a dozen research areas within the country. This proposed monitoring methodology requires pilot studies to be carried out within Neptis rivularis occurrence sites in order to assess the effectiveness of the presented assumptions of the monitoring methodology for this species.
\end{abstract}

Key words: Hungarian Glider, Neptis rivularis, Spiraea salicifolia, monitoring.

\section{INTRODUCTION}

The aim of this study was to propose methods of monitoring in Poland the species Neptis rivularis.

\section{DESCRIPTION OF THE SPECIES}

Hungarian Glider - Neptis rivularis (Scopoli, 1763) is a species of butterfly in the family Nymphalidae. Neptis rivularis s a medium-sized butterfly with a wingspan of $44-54 \mathrm{~mm}$. Sexual dimorphism is poorly visible - the female is larger than the male. The top of the wings is blackbrown with a white drawing. On the front wing, there is a base streak composed of a few tiny white spots. The headband is folded up from white separate spots of different sizes.

Corresponding author: Kalina Wnorowska, Faculty of Animal Breeding, Bioengineering and Conservation, Warsaw University of Life Sciences - SGGW, Józefa Ciszewskiego 8, 02-786 Warszawa, Poland, e-mail: kalinawnorowska@gmail.com. 
At the outer edge of the wing, there may sometimes be small fuzzy whitish lines. On the rear wing, the headband is single and wide. The underside of the wings is light brown with a white drawing, and the drawing elements are arranged similarly at the top of the wings (Buszko and Masłowski 2008).

The eggs are spherical, slightly elongated, gray-greenish in color. There are numerous indentations on the surface of the egg, which look like a honeycomb structure. In addition, the chorion (casing) is covered with fine bristles (own observations).

Buszko and Masłowski (2008) reported that the caterpillars are brown, lighter on the dorsal side, additionally they have oblique, darker spots. On the second and eighth abdominal segments, as well as on the mid- and trunk, there are pairs of short sparrowed appendages.

The pupae are hanging, brown in color, with a delicate mesh pattern and a dark spot in the center of the wing covers. Wing covers stand out strongly. A sharp crest runs along the ridge, dark in the front part, and whitish with a dark edge further down. On the sides of the abdomen, long dark stripes and thin diagonal lines (Fig. 1-4).

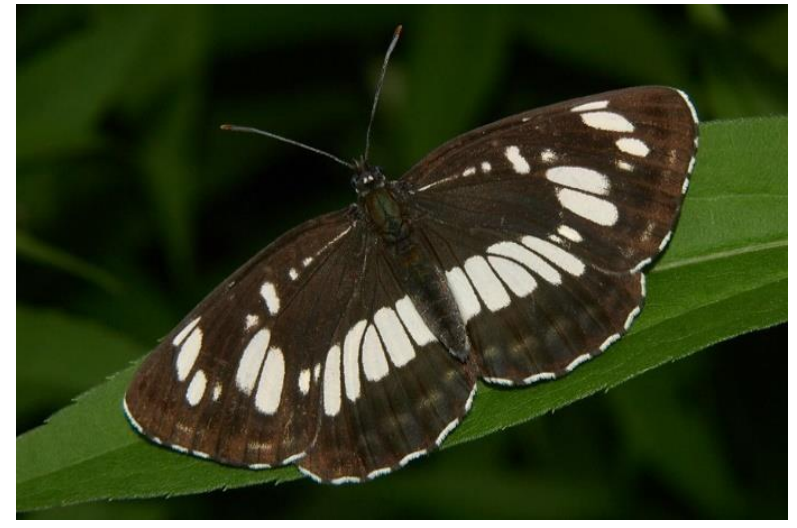

Fig. 1. Neptis rivularis imago (photo J. Bury)

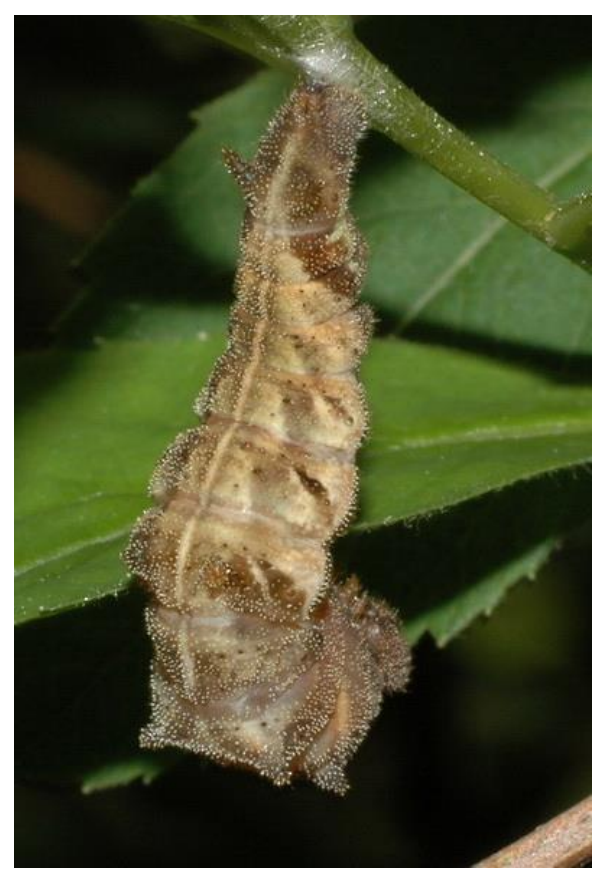

Fig. 3. Neptis rivularis prepupa (photo J. Bury)

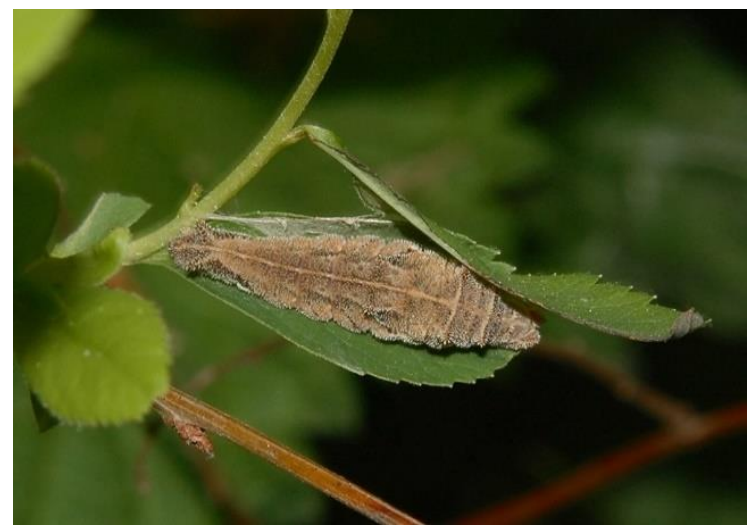

Fig. 2. Neptis rivularis caterpillar (photo J. Bury)

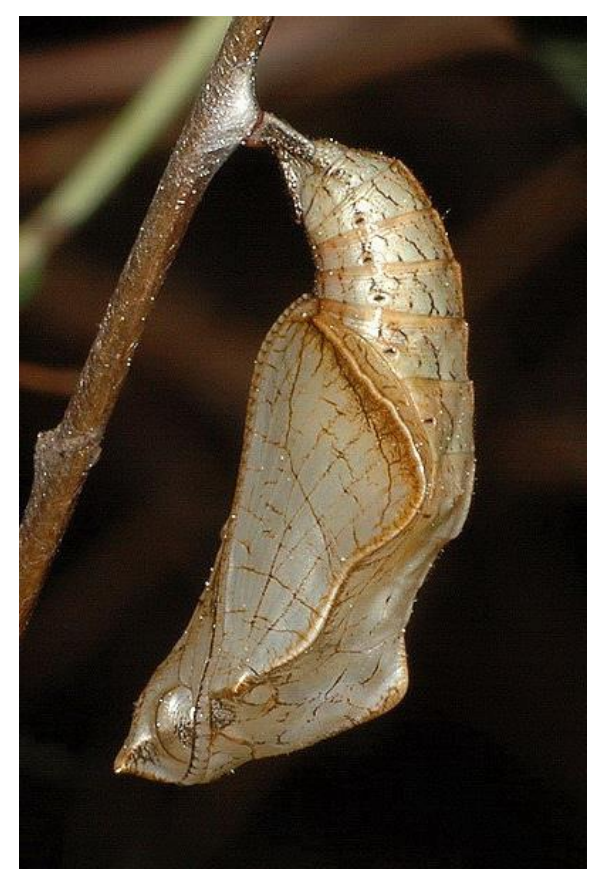

Fig. 4. Neptis rivularis pupa (photo J. Bury) 


\section{BIOLOGY OF THE SPECIES}

Neptis rivularis is a one-generation species, found in Poland from mid-June to the third decade of July. In warmer years, it even appears in the first decade of June. Adult stage of butterflies feed on the nectar of flowers - mainly Spiraea salicifolia. Butterflies also visit flowers, especially white ones, such as: yarrow (Achillea millefolium), umbellate (Apiaceae), blackberries (Rubus L.) and black locust (Robinia pseudoacacia L.). They also eat honeydew secreted by aphids (Warecki 2010).

The eggs are laid on both sides of the host leaf. During the day, the caterpillar feeds on the leaves of the bridewort - in Poland only on the Spiraea salicifolia. Young caterpillars gnaw the leaves below the apex, on each side from the edge of the lamina to the midline, and then interlock the edges with a silk thread, creating a tubular shelter (hibernaculum) in which they stay (Fig. 5).

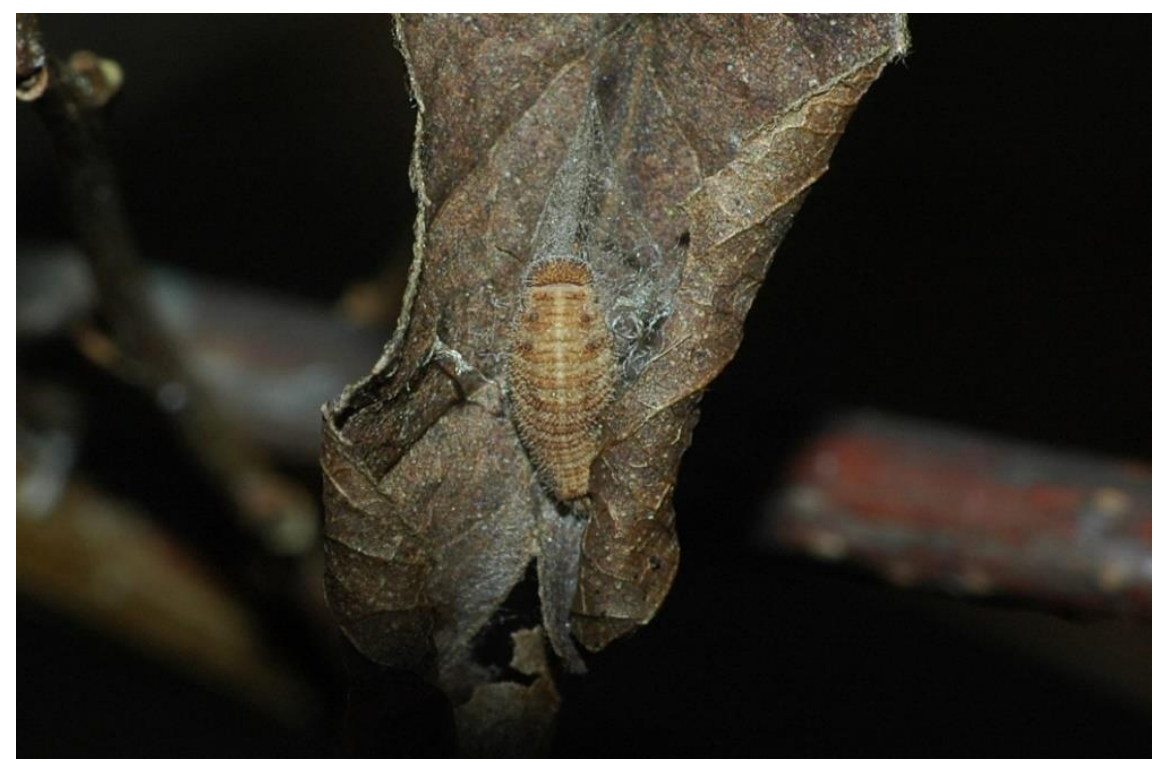

Fig. 5. Hibernaculum of Nepits rivularis (photo J. Bury)

\section{HABITAT REQUIREMENTS}

Neptis rivularis inhabits the deciduous forest zone of the Palearctic. In Poland it is currently the only representative of the genus. It is associated with overexposed, wet forest biotopes in which the host plant occurs.

In Poland, caterpillars are monophagous and feed only on the Spiraea salicifolia (Sielezniew and Dziekańska 2010). Spiraea salicifolia is a shrub of the Rosaceae family, which grows insular in Poland, reaching the northern limit of its range in the south-eastern part of the country (Zając and Zając 2001). The natural range of the Spiraea salicifolia in Europe and Poland is difficult to determine due to the garden cultivation that has been going on since the end of the 16th century and the penetration of plants into forest habitats (Browicz 1963). Due to the specificity of the Spiraea salicifolia, Neptis rivularis is insular. Butterflies are tied to a small area, sometimes several dozen meters, and rarely leave it (Fig. 6). 


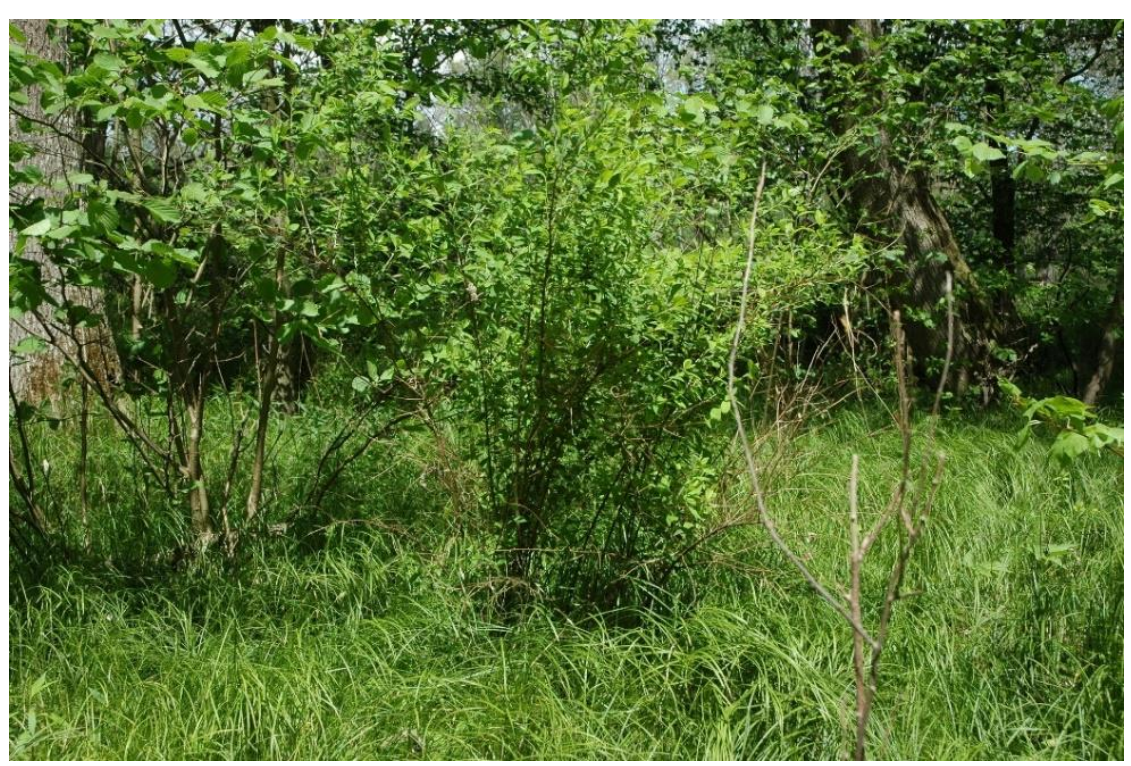

Fig. 6. An example of a Neptis rivularis habitat (photo J. Bury)

\section{DISTRIBUTION OF THE SPECIES IN POLAND}

The species is found in a narrow zone from eastern France and northern Italy to Japan (Buszko and Masłowski 2008; Mérit and Manil 2016). In Poland, the distribution of the species is closely related to the distribution of the Spiraea salicifolia L. It is known in several island ranges in the vicinity of Starachowice, the Sandomierska Valley (Lipskie Forests, Sandomierz Primeval Forest), as well as in the Solska Primeval Forest and Sub-Carpathian region (WIOŚ 2003; Warecki 2010). It can also be found on the Tarnogrodzki Plateau, locally in the Low Beskids. The largest populations are in the Sandomierz Basin. Figure 7 shows the distribution of Neptis rivularis in Poland by districts.

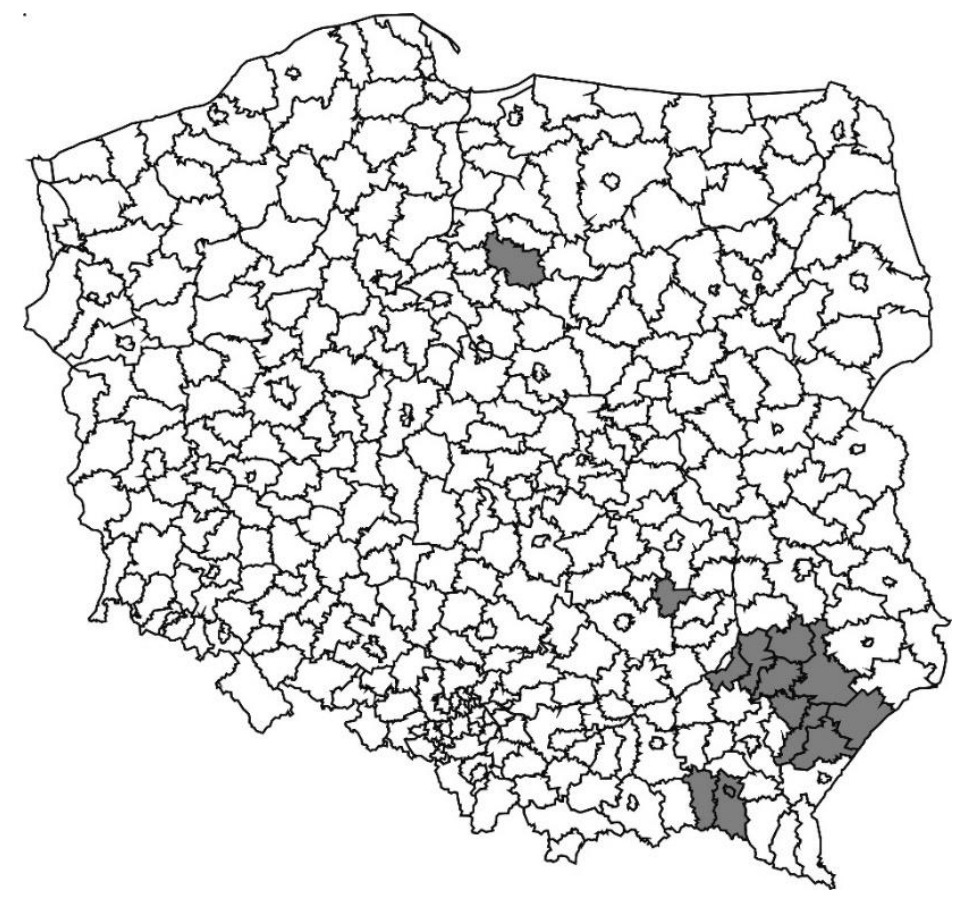

Fig. 7. Map of the distribution of Neptis rivularis in Poland by districts (based on: Kata 1999; Błoński and Gwardjan 2016; Buszko 2017; Buszko and Nowacki 2017) 
Due to the small number of localities in the country and their gradual disappearance as a result of habitat changes, the species was partially protected and placed on the Red list of threatened animals in Poland and Polish Red Book of Animals with EN category (Buszko and Nowacki 2002; Nowak 2011; DzU z 2016 r. poz. 2183). On European Red List of Butterflies $N$. rivularis is assigned to LC category (least concern), but on the Carpathian Red List of Forest Habitats and Species to VU category (vulnerable) (van Swaay et al. 2010; Kalivoda et al. 2014). With the same VU category $N$. rivularis is on Carpathian List of Endangered Species (Witkowski et al. 2003).

\section{CONCEPT OF THE SPECIES MONITORING}

Poland is not monitoring the Neptis rivularis. The last inventory studies were carried out in the 1990s during the collection of data for the Atlas of diurnal distribution of butterflies by Buszko (1997). The then inventory was aimed at examining the range of this species in Poland. The presence of the Neptis rivularis is found nationally during biodiversity studies in selected areas, but these are general studies, not focused on a specific species. In 2016, Błoński and Gwardjan carried out a study to confirm the presence of known Neptis rivularis sites and the detection of new ones by conducting checks in potential, favorable conditions in forest areas belonging to the Starachowice and Suchedniów forest districts.

Nepits rivularis is a convenient species for monitoring, because it is easy to indicate potential places of its occurrence ( $S$. salicifolia locations in riparian habitats), and individuals are easy to observe in the field, both for adults and caterpillars that live on the host plant and create a characteristic shelter by coupling the edges of the leaves.

The proposed method of monitoring in this study (counting on transects) is identical to other diurnal butterfly monitoring programs in Poland. Moreover, the concept of monitoring the $N$. rivularis is similar to the one used in studies of other daytime butterflies (Pollard and Yates 1993). In other European countries, the number of day butterflies is estimated in a similar way (Bolz 2003).

The suggested method of assessing the $N$. rivularis population is based on the spring or summer counts of adults and the counting of late summer caterpillars on transects, in line with the methodology used for most other butterfly species (Sielezniew 2012). Monitoring will also determine the isolation of the monitored population, which is extremely important as it allows for an analysis of whether the studied local population has the potential conditions for functioning in the metapopulation system.

In order to assess the condition of the habitat while monitoring, it was initially proposed to include indicators such as the presence of caterpillars hosts before wintering and the exposure on the sun of the microhabitat in the larva stage.

It should be remembered the possibility of modifying the method of habitat assessment as the knowledge of the habitat preferences of the studied species is expanded.

\section{INDICATORS}

The methodology developed for monitoring Neptis rivularis is based on counting adults and caterpillars on transects, and the presence of caterpillars hosts plant before hibernation and the solar exposure of the microhabitat in the larva stage. It is a simple method that does not require specialist knowledge, as the adult form and the caterpillar of Neptis rivularis are 
characteristic. Moreover, they occur where the presence of Spiraea salicifolia is recorded. The advantage of this method is also non-invasiveness. However, the method, depends on the weather conditions, because on rainy days, the observation of butterflies may be difficult or impossible. The evaluation system presented in this method was taken from publication of Makomaska-Juchiewicz (2010).

The proposed monitoring methodology of Neptis rivularis takes into account population condition indicators and habitat status indicators. Table 1 presents the population condition indicators adopted in methodology of monitoring Neptis rivularis in Poland.

Table 1. Indicators population condition of Neptis rivularis

\begin{tabular}{lll}
\hline \multicolumn{1}{c}{ Indicator } & \multicolumn{1}{c}{ Measurement unit } & \multicolumn{2}{c}{ Method of measurement/definition } \\
\hline Number of adults & number of adults $/ 100 \mathrm{~m}$ & $\begin{array}{l}\text { The indicator is defined as the maximum number } \\
\text { of adults observed on the transect during one } \\
\text { observation season }(4-5 \text { controls) per } 100 \mathrm{~m} \text { length }\end{array}$ \\
\hline Index of abundance & number of adults $/ 100 \mathrm{~m}$ & $\begin{array}{l}\text { The sum of the counts of individual observations on } \\
\text { the transect during one observation season, given per } \\
100 \mathrm{~m} \text { of the length of the transect }\end{array}$ \\
\hline $\begin{array}{l}\text { Number of } \\
\text { caterpillars }\end{array}$ & number of caterpillars $/ 100 \mathrm{~m}$ & $\begin{array}{l}\text { The indicator is defined as the number of caterpillars } \\
\text { found in a strip up to } 10 \mathrm{~m} \text { from the center of the } \\
\text { transect, used for imago counts, per } 100 \mathrm{~m} \text { of strip } \\
\text { length }\end{array}$ \\
\hline Isolation* & $\mathrm{km}$ & $\begin{array}{l}\text { The indicator defined as the distance in } \mathrm{km} \text { from } \\
\text { the nearest inhabited site based on the map }\end{array}$ \\
\hline
\end{tabular}

* The index describing isolation relative to other known populations allows for the chance of re-supplying the population due to immigration of individuals from outside. During the valorization of this indicator, it was taken that Neptis rivularis creates sedentary populations that function in the metapopulation system.

The method of valorization of population condition indicators is presented in Table 2.

Table 2. Valorization of Neptis rivularis population condition

\begin{tabular}{lccc}
\hline \multirow{2}{*}{ Indicator } & \multicolumn{3}{c}{ Evaluation } \\
\cline { 2 - 4 } & FV & U1 & U2 \\
\hline Number of adults & $>8 / 100 \mathrm{~m}$ & $4-8 / 100 \mathrm{~m}$ & $<4 / 100 \mathrm{~m}$ \\
\hline Index of abundance & $>20 / 100 \mathrm{~m}$ & $10-20 / 100 \mathrm{~m}$ & $<10 / 100 \mathrm{~m}$ \\
\hline Number of caterpillars & $>8 / 100 \mathrm{~m}$ & $3-8 / 100 \mathrm{~m}$ & $<3 / 100 \mathrm{~m}$ \\
\hline Isolation & $<2 \mathrm{~km}$ & $2-15 \mathrm{~km}$ & $>15 \mathrm{~km}$ \\
\hline
\end{tabular}

FV - favorable, U1 - unfavorable/inadequate, U2 - unfavorable/bad.

The assessment of the population condition is determined by the assessment of the worst rated indicator - if the size of the population is $\mathrm{U} 1$ and isolation is FV, then the assessment of the population condition is $U 1$.

Habitat status indicators are summarized in Table 3.

Table 3. Indicators of the habitat of Neptis rivularis

\begin{tabular}{lll}
\hline \multicolumn{1}{c}{ Indicator } & Measurement unit & \multicolumn{1}{c}{ Method of measurement/definition } \\
\hline Occurrence of host plants & number of plants $/ 100 \mathrm{~m}$ & $\begin{array}{l}\text { Counting along the transect of caterpillars host } \\
\text { bushes (field measurement) }\end{array}$ \\
\hline $\begin{array}{l}\text { Solar exposure } \\
\text { of microhabitats }\end{array}$ & descriptive indicator & $\begin{array}{l}\text { Determination of the caterpillars exposure to one } \\
\text { of the eight sides of the compass (measured with } \\
\text { a compass) }\end{array}$ \\
\hline
\end{tabular}


The method of valorization of habitat condition indicators is presented in Table 4.

Table 4. Valorization of habitat condition indicators of Neptis rivularis

\begin{tabular}{lccc}
\hline \multirow{2}{*}{ Indicator } & \multicolumn{3}{c}{ Evaluation } \\
\cline { 2 - 4 } & $\mathrm{FV}$ & $\mathrm{U} 1$ & $\mathrm{U} 2$ \\
\hline Occurrence of host plants & $>15 / 100 \mathrm{~m}$ & $5-15 / 100 \mathrm{~m}$ & $<5 / 100 \mathrm{~m}$ \\
\hline Solar exposure of microhabitats & $\mathrm{S}, \mathrm{SW}, \mathrm{W}$ & $\mathrm{NW}, \mathrm{SE}$ & $\mathrm{N}, \mathrm{NE}, \mathrm{E}$ \\
\hline
\end{tabular}

FV - favorable, U1 - unfavorable/inadequate, U2 - unfavorable/bad.

For each evaluation of the indicator a certain number of points should be awarded: for FV - 2 points, for U1 - 1 point, for U2 - 0 points. The total assessment for the condition of the population is as follows: $3-4$ points - FV good, 2 points - U1 unsatisfactory, 0-1 point U2 bad.

\section{PERSPECTIVE}

Increasingly, the habitats of the $N$. rivularis are subject to various types of anthropogenic transformations. This makes it necessary to evaluate the prospects for the conservation of this species. Such an assessment should include forecasting whether the land development method will undergo changes in the future, and whether these changes will contribute to the maintenance of the set of habitat conditions.

Habitat deterioration can be caused by many factors, the most important of which are: clearing trees, excessive afforestation or carrying out investments such as building highways or clearing forests for housing estates. On the other hand, the lack of use may lead to a progressive natural succession, and this affects the increase in shade and the possibility of loss of host plants. Among human-dependent activities, which may be neutral to the habitat should also be mentioned the use of plant protection products, which can contribute to an increase in population of $N$. rivularis mortality.

Isolation also influences the assessment of the prospects for the conservation of a species. Isolation reduces the chances of a population surviving. The main reason is the unfavorable genetic effects in populations which are limited in size. In addition, the mating of individuals in relatedness contributes to an increase in homozygosity among the offspring, which may result in higher mortality. Moreover, genetic drift may cause a decrease in population variability. This may cause a reduction in the adaptability of individuals. Migrations between populations are an important factor, as they eliminate adverse genetic effects, therefore the sites located within a compact species range have predictably better survival prospects than marginal populations.

The assessment should be carried out on a scale:

FV - no threats and significant impacts, it can be predicted that the current good condition of the population and habitat will continue in the next decade or that it will improve when there is a species protection plan in a given area.

$\mathrm{U} 1$ - the prognosis is not very favorable, there is a risk of deterioration of the present good condition of the population and habitat due to human activity or the unsatisfactory current condition will persist due to the failure to take protective measures.

$\mathrm{U} 2$ - bad prospects, it can be assumed that the current condition of the population will deteriorate due to the impact of planned investments or that the current bad condition will continue due to the size of the population and too much isolation. 


\section{GENERAL EVALUATION}

When making the overall assessment, attention should be paid to the state of the population and the condition of habitats and prospects for the preservation of the species. The lowest rated parameter determines the overall rating.

\section{The method of performing the research}

The habitat of the $N$. rivularis consists of areas with overexposed, wet forest biotopes where the presence of the Spiraea salicifolia is recorded. Preferred are linear positions - transects with a length of 300-600 m. Taking into account the distribution of the species in Poland, the national monitoring should cover a few to a dozen sites in the main areas of the species occurrence (Sandomierz Basin - Lipskie Forest, Sandomierska Primeval Forest; close vicinity of Starachowice, Solska Primeval Forest, Subcarpathia region). Key areas for the Neptis rivularis with UTM codes, where 1-2 monitoring sites should be designated are presented in the Table 5.

Table 5. The areas of occurrence of Neptis rivularis (based on: Buszko 1997; Kata 1999; Błoński and Gwardjan 2016; Bury 2019)

\begin{tabular}{ll}
\hline \multicolumn{1}{c}{ Position } & UTM \\
\hline Rzepin & EB04 \\
\hline Młynówka & EB05 \\
\hline Bugaj & EB06 \\
\hline Cieplice, Rudka, Wylewa, Pigany, Paluchy, Głogowiec & FA16 \\
\hline Nowy Dzików, Zabiała & FA26 \\
\hline Wola Cewkowska, Cewków, Lebiedzie, Stary Dzików, Miłków & FA36 \\
\hline Czerwona Wola, Zastawne, Radawa, Biała Góra, Nielepkowice, Łapajówka, Cetula, Skrutaki & FA25 \\
\hline Wola Mołodycka, Karczmarze, Stare Sioło, Surmaczówka, Wólka Zapałowska, Lipina & FA35 \\
\hline Florianka & FB40 \\
\hline Panasówka & FB30 \\
\hline Buda Stalowska & EA59 \\
\hline
\end{tabular}

Before starting the field monitoring tests, if the tests are performed for the first time, the location and the transect location should be determined on the basis of early field reconnaissance and available cartographic data. The research should not be selected only in places where the presence of the $N$. rivularis has been previously found, but attention should be paid to the presence of an appropriate habitat so that there is a real chance for the presence of the species. To ensure repeatability of monitoring tests in the future care to precisely define the position of the test area. Landmarks such as roads, drainage ditches, railway lines, forest edges etc. are helpful to determine the location of the transect in the field. The course of the transect should be determined by using GPS and then displayed on a map, e.g. in Google Earth.

Nepits rivularis is a species whose presence is quite easy to determine, as butterflies attract the attention of the observer due to the color of their wings, caterpillars feed on the Spiraea salicifolia and spin characteristic leafworms. On the other hand, the possibility of species 
monitoring is limited by the relatively short detection period. Moreover, the places of its occurrence are sometimes hidden inside wet forests (primeval forests) and in hard-to-reach parts - near river valleys. The counting results may also be influenced by unfavorable weather conditions and weather anomalies during the hatching and mating season of butterflies in a season.

The measure of the index is the maximum number of adults per $100 \mathrm{~m}$ in a 300-600 $\mathrm{m}$ long transect, depending on the site. Butterflies are counted using the Pollard Method (van Swaay et al. 2008; Sevilleja et al. 2019). The transect should be divided into sections (e.g. $100 \mathrm{~m}$ ), depending on the habitat variability - plant cover, morphology - on which the counting is performed. Butterflies should be counted five times on the transect in the expected flight period $-2 / \mathrm{VI}-3 / \mathrm{VII}$, assuming one observation per week. The earlier appearance of the butterfly should be taken into account in warmer summers. Butterflies should be counted between 12.00 and 18.00, in favorable weather conditions - in light cloudiness, light or moderate wind, with the frequency of one observation per week during the expected appearance of the butterfly on the site. The classic method of transect assumes one observation per week. Any derogation from this rule is possible only in the case of natural disasters or other serious mishaps. The abundance index is the sum of the counts of individual observations on the transect during one observation season, given per $100 \mathrm{~m}$ of the length of the transect.

In the absence of any of these observations, an estimate should be made based on the average of the decade preceding and following the decade in which the observation was not possible.

In a strip $10 \mathrm{~m}$ wide and up to 2-3 $\mathrm{m}$ high, along the transect marked out for the study of adult butterflies, should find plants - Spiraea salicifolia on which the eggs are laid and count the observed caterpillar. The check should be done in late summer. This indicator does not allow to determine the number of caterpillars, however, the number of observed species may indicate the viability of the local population. The indicator can also be used to verify the results obtained with the use of the first two indicators. Field work of counting adults and caterpillars requires 2-3 hours for one control. The location of the caterpillar should be noted in relation to the designated transect for butterflies and the plants on which caterpillars are located.

The degree of isolation of a population from other populations of a species is expressed as the distance in kilometers to the closest active site of the species. It is determined on the basis of the current knowledge of the species distribution in the light of recent publications (Buszko and Nowacki 2002; Błoński and Gwardjan 2016), as well as all available unpublished data and own observations. A GPS receiver should be used to measure the distance between sites. When analyzing this indicator, other elements of the environment, i.e. barriers that may limit dispersion, are not included.

The number of the caterpillars host plant should be determined before wintering. During the last transect inspection in August/September, the host plants - Spiraea salicifolia should be counted along the transect and the obtained value should be converted into a $100 \mathrm{~m}$ section.

The solar exposure of microhabitats is defined as the exhibition of the route to one of the eight parts of the compass: N, NE, E, SE, S, SW, W, NW. Usually in this species, the caterpillars are not located in the shady interior of the forest, but along roads and in forest clearings. It is then possible to determine the exposure of caterpillars to sunlight in the middle of the day between 11.00 and 15.00. During this time, the caterpillars are the most active. In a semi-open area, this indicator is synonymous with the determination of the side of a tree or shrub on which there is a caterpillar/caterpillars. 
Additionally, during field work, it is recommended to collect data on their nests:

- occurrence of plants whose nectar is eaten by adult individuals, such as black locust, blackberries, yarrow;

- health condition of the host plants at the position;

- GPS position of the caterpillars or the location of them on the transect diagram;

- height of the caterpillars above the ground.

Field studies should be performed in late spring and summer. The dates of $4-5$ of the recommended inspections are between the second decade of June and the third decade of July and in August for the control of caterpillars and caterpillars host plants.

With the current knowledge about the species, it is difficult to determine the frequency with which monitoring should be carried out, as the seasonal fluctuations in the size of the population and the rate of changes in the species habitat are not known. In order to capture possible trends in the species abundance, counting on transects should be performed as often as possible. Annual monitoring is recommended, at least at some selected sites from various regions of the country. Table 6 shows an example of a completed species observation sheet.

Table 6. Example of completed species observation sheet

\begin{tabular}{|c|c|}
\hline Species name & $\begin{array}{c}\text { English and Latin name, name of author according to current nomenclature } \\
\text { Hungarian Glider Neptis rivularis (Scopoli, 1763) }\end{array}$ \\
\hline $\begin{array}{l}\text { Protected areas in which the } \\
\text { site is located }\end{array}$ & $\begin{array}{l}\text { Natura 2000, national and landscape parks, nature reserves and others: } \\
\text { Roztocze National Park }\end{array}$ \\
\hline Locality name & Name of the monitored locality \\
\hline Site type & Reference/research: research \\
\hline Geographical coordinates & Enter geographical coordinates (GPS): N XXXX'XX.X" E XXXX'XX.X" \\
\hline Altitude above sea level & Specify the altitude above sea level of the site: $150-155 \mathrm{~m}$ above sea level \\
\hline Area of the site & Specify the area of the site - ha, a or $m^{2}$ : difficult to quantify \\
\hline Position description & $\begin{array}{l}\text { Provide a description allowing identification in the field: } \\
\text { The position is located in the Roztocze National Park near of the village } \\
\text { Panasówka. Between the villages... and... you should turn into the forest road } \\
\text { leading to the inactive railway stop called... There is a } 400 \mathrm{~m} \text { long transect at } \\
\text { the site. The location is given for the middle of the transect. }\end{array}$ \\
\hline $\begin{array}{l}\text { Description of the habitat in } \\
\text { the locality }\end{array}$ & $\begin{array}{l}\text { Short characteristics of the habitat: general character, habitat type, solar } \\
\text { exhibition, types of habitats in the vicinity of the site. } \\
\text { General character: the road and the edge of the forest clearing. } \\
\text { Natural habitat type: riparian forest. } \\
\text { Exhibition: variable. } \\
\text { Types of habitats in the vicinity of the site: hay meadow and bright forest }\end{array}$ \\
\hline $\begin{array}{l}\text { Information of the species in } \\
\text { the locality }\end{array}$ & $\begin{array}{l}\text { Short information about the species occurrence at the site, incl. when it was first } \\
\text { discovered, research to date and other pertinent facts; research results from the } \\
\text { years preceding the monitoring: } \\
\text { Examined in detail for the first time; the research so far has been limited to } \\
\text { finding the species without specifying the population and habitat status }\end{array}$ \\
\hline $\begin{array}{l}\text { Is monitoring required in } \\
\text { subsequent years? }\end{array}$ & $\begin{array}{l}\text { Enter yes/no; in case of "no", justification should be given as to why it is proposed } \\
\text { to resign from this post: } \\
\text { yes - the exemplary nature of the habitat and high abundance }\end{array}$ \\
\hline Observer & Name and surname of the observer \\
\hline Observation dates & $\begin{array}{l}\text { Dates of all observations: } 3.06 .2020,10.06 .2020,17.06 .2020,24.06 .2020 \text {, } \\
1.07 .2020\end{array}$ \\
\hline
\end{tabular}


Table 7 shows an example of how to fill in a "Conservation status of the species" sheet.

Table 7. Conservation status of the species

\begin{tabular}{ccc}
\hline Parameter/indicators & Indicator value and commentary & Assessment \\
\hline population & \\
\hline
\end{tabular}

\begin{tabular}{|c|c|c|c|}
\hline Number of adults & $\begin{array}{l}\text { Enter the number } / 100 \mathrm{~m} \text { (the maximum value from the checks } \\
\text { carried out): } 7.6 / 100 \mathrm{~m} \\
\text { Enter the results of all counts, including the date and number of } \\
\text { specimens. } \\
\text { Enter the total length of the transect: } \\
7 \text { June }-5,15 \text { June }-20,25 \text { June }-45 \text {, VIII - } 28 \text { caterpillars } \\
\text { length of the transect about } 400 \mathrm{~m}\end{array}$ & FV & \multirow{4}{*}{$\mathrm{U} 1$} \\
\hline Index of abundance & 12,83 & $\mathrm{U} 1$ & \\
\hline $\begin{array}{l}\text { Number of } \\
\text { caterpillars }\end{array}$ & $\begin{array}{l}\text { Enter the number of lines } / 100 \mathrm{~m} \text { of the transect: } \\
5.17 \text { caterpillars per } 100 \mathrm{~m} \text { of the transect } \\
\text { Enter the location of the host plant on which the caterpillars are } \\
\text { located: caterpillars located along the transect line, almost evenly } \\
\text { spaced on both sides, all on a S. salicifolia }\end{array}$ & U1 & \\
\hline Isolation & $\begin{array}{l}\text { Enter the distance to the nearest inhabited position: } \\
\text { about } 4 \mathrm{~km} \text { (forest..., river...) }\end{array}$ & $\mathrm{FV}$ & \\
\hline \multicolumn{4}{|c|}{ habitat } \\
\hline Food base & $\begin{array}{l}\text { Enter the number of host plants } / 100 \mathrm{~m} \text { of transect: } \\
14.2 \text { bushes: additionally, black locust and blackberry were found } \\
\text { near the transect }\end{array}$ & FV & \multirow{2}{*}{ FV } \\
\hline $\begin{array}{l}\text { Solar exposure } \\
\text { of microhabitats }\end{array}$ & Enter the solar exposure of microhabitats: S, SW, W, NW & $\mathrm{FV}$ & \\
\hline
\end{tabular}

Brief forecast of the population and habitat status of the species
at the site in the perspective of 10-15 years in relation to their
current condition and observed change trends:

Table 8 shows an example of how to fill the worksheet to obtain additional information on the most important current and anticipated impacts (threats) on the species and its habitat at the site studied. 
Table 8. Most important current and anticipated impacts on Neptis rivularis and its habitat

\begin{tabular}{|c|c|c|c|c|}
\hline \multicolumn{5}{|c|}{ Current impacts } \\
\hline code & the name of the activity & intensity & impact & short description \\
\hline 990 & $\begin{array}{l}\text { change of species composition } \\
\text { (succession) }\end{array}$ & $\mathrm{C}$ & 0 & $\begin{array}{l}\text { It is not known what stage of forest } \\
\text { succession is optimal for the species }\end{array}$ \\
\hline \multicolumn{5}{|c|}{ Threats (future, anticipated impacts) } \\
\hline 161 & afforestation & C & - & $\begin{array}{l}\text { Further afforestation of the existing } \\
\text { gaps and forest clearings used by the } \\
\text { pastures cannot be ruled out. This } \\
\text { would increase the shadows and } \\
\text { displace the } S \text {. salicifolia }\end{array}$ \\
\hline 973 & diseases & C & - & $\begin{array}{l}\text { S. salicifolia is a disease resistant plant, } \\
\text { but it can be attacked by fungal } \\
\text { diseases, powdery mildew (Erysiphe } \\
\text { polygoni) or leaf blotch (Cercospora) }\end{array}$ \\
\hline \multicolumn{5}{|c|}{ Other informations } \\
\hline \multicolumn{5}{|c|}{$\begin{array}{l}\text { Other observed animal and plant species listed in the Habitats } \\
\text { and Birds Directives, endangered and rare species, protected } \\
\text { species (indicate the abundance on the scale: abundant, } \\
\text { medium, rare): } \\
\text { The Great Capricorn Beetle Cerambyx credo - rare here }\end{array}$} \\
\hline Alien a & d invasive species & \multicolumn{3}{|c|}{$\begin{array}{l}\text { Observed alien and invasive species: } \\
\text { Robinia acacia Robinia pseudoacacia L. - moderately } \\
\text { numerous }\end{array}$} \\
\hline $\begin{array}{l}\text { Protec } \\
\text { effecti }\end{array}$ & $\begin{array}{l}\text { ve activities and assessment of their } \\
\text { eness }\end{array}$ & \multicolumn{3}{|c|}{$\begin{array}{l}\text { For example, strict protection, mowing, increasing the water } \\
\text { level, grazing, other restoration activities: } \\
\text { Pest control with insecticide spraying waived - temporarily } \\
\text { effective }\end{array}$} \\
\hline $\begin{array}{l}\text { Propo } \\
\text { measu }\end{array}$ & $\begin{array}{l}\text { s for introducing protective } \\
\mathrm{s}\end{array}$ & \multicolumn{3}{|c|}{ As above: no suggestions } \\
\hline Metho & ological notes & \multicolumn{3}{|c|}{$\begin{array}{l}\text { Information important for further monitoring planning: } \\
\text { The optimum appearance of butterflies in the south-eastern part } \\
\text { of the country is } 10-14 \text { days later than in the south-western part }\end{array}$} \\
\hline Other & marks & \multicolumn{3}{|c|}{$\begin{array}{l}\text { Enter any information that helps to interpret the results, e.g. } \\
\text { weather anomalies, high water level, etc.: } \\
\text { Numerous and intense rainfalls in June and July } 2020 \text { made it } \\
\text { difficult to properly monitor and could have had an impact on the } \\
\text { lowering of the results of counting butterflies and moths }\end{array}$} \\
\hline $\begin{array}{l}\text { Photo } \\
\text { docum }\end{array}$ & $\begin{array}{l}\text { aphic and cartographic } \\
\text { ntation }\end{array}$ & \multicolumn{3}{|c|}{$\begin{array}{l}\text { Attachments to the database (in electronic version): } \\
\text { at least } 2 \text { photos per site (species, habitat), the boundaries } \\
\text { of the research area marked on the appropriate cartographic } \\
\text { background }\end{array}$} \\
\hline
\end{tabular}

Impact influence: "+" - positive, "-" - negative, "0" - neutral; impact intensity: A - strong, B - moderate, C - weak.

\section{CONCLUSIONS}

In the past, Neptis rivularis, was under strict protection in Poland, but now is under partial protection. On the Red list of threatened animals in Poland and in the Polish Red Book of Animals it is marked as a very high-risk species, highly endangered. On the Red List of Butterflies of Europe $N$. rivularis is marked with the LC category - not endangered, less care. In turn, on the Carpathian Red List of Forest Habitats and Species, and on Carpathian 
List of Endangered Species, $N$. rivularis is marked as vulnerable to extinction species. The change in the protective status of the $N$. rivularis in Poland may result from the growing social awareness, as well as from large-scale activities such as the designation of Natura 2000 areas or the creation of nature reserves with valuable natural resources. $N$. rivularis is a species closely related to the occurrence of the host plant $-S$. salicifolia. The unique habitat of this butterfly is areas around Starachowice, there are known permanent locations of the species and annual occurrences of butterflies are recorded.

The protection of the $N$. rivularis depends to a large extent on the preservation of small luminous forest stands in the landscape and the protection of the $S$. salicifolia. First of all, the condition of the species population depends on the actions taken in the spatial development model, as many valuable habitats are destroyed as a result of e.g. construction investments. Currently, the greatest threat to the species is the elimination of the $S$. salicifolia sites and use strong plant protection products by the agricultural sector, which may have an impact on the increase in butterfly mortality. On the other hand, leaving habitats to natural succession may lead to significant shading which deteriorates the quality of habitats. In places where $N$. rivularis occurs, it is necessary to implement protection programs to maintain the appropriate condition of habitats - the cutting of tall trees and shrubs, especially shading of bushes of the $S$. salicifolia. The way to increase the occurrence of the $N$. rivularis may require planting of $S$. salicifolia along forest roads or on the edge of forests.

The presented concept of monitoring methodology can be applied to the control of endangered species of other daytime butterflies closely related to forest habitats, such as: Limenitis spp. or Apatura spp.

\section{REFERENCES}

Błoński W., Gwardjan M. 2016. Występowanie pasyna lucylla Neptis rivularis (Scopoli, 1763) (Lepidoptera: Nymphalidae) i jego rośliny żywicielskiej - tawuły wierzbolistnej Spiraea salicifolia Linnaeus, 1753 (Rosaceae) w okolicach Starachowic [Occurence of the Hungarian Glider Neptis rivularis (Scopoli, 1763) (Lepidoptera: Nymphalidae) and its food plant - Bridewort Spiraea salicifolia Linnaeus, 1953 (Rosaceae) near Starachowice]. Naturalia 5, 126-131. [in Polish]

Bolz R. 2003. Euphyryas maturna (Linnaeus, 1758), in: B. Petersen, G. Ellwanger, G. Biewald, U. Hauke, G. Ludwig, P. Pertscher, E. Schröder, A. Ssymank, Das europäische Schutzgelbietssystem Natura 2000. Ökologie und Verbereitung von Arten der FFH-Richlinie in Deutschland. Band 1: Pflanzen und Wirbellose. Schr. R. Landschaftspflege Natruschutz. 69, 473-478. [in German]

Browicz K. 1963. O geograficznym rozmieszczeniu tawuły bawoliny (Spiraea salicifolia L.) w Polsce. Rocz. Sekc. Dendrol. Pol. Tow. Bot. 17, 73-90. [in Polish]

Bury J. 2019. Motyle dzienne (Rhopalocera: Hesperioidea i Papilionoidea) Sieniawskiego Obszaru Chronionego Krajobrazu oraz Specjalnego Obszaru Ochrony Siedlisk „Lasy Sieniawskie” (PLH180054) Sieci Natura 2000 [Butterflies (Rhopalocera: Hesperioidea \& Papilionoidea) of the Sieniawa Landscape Protected Area (SE Poland) and the Special Area of Conservation "Lasy Sieniawskie" (PLH180054) in the Natura 2000 network]. Prz. Przyr. 2, 68-88. [in Polish]

Buszko J. 1997. Atlas rozmieszczenia motyli dziennych w Polsce 1986-1995. Toruń, Turpress [in Polish]

Buszko J. 2017. The distribution atlas of butterflies in Poland. Nicolaus Copernicus University of Toruń, https://doi.org/10.15468/yqzyas, access: 22.07.2021.

Buszko J., Masłowski J. 2008. Motyle dzienne Polski. Nowy Sącz, Wydaw. Koliber, 175-176. [in Polish]

Buszko J., Nowacki J. 2002. Lepidoptera Motyle, in: Czerwona lista zwierząt ginących i zagrożonych w Polsce. Ed. Z. Głowaciński. Kraków, IOP PAN. [in Polish] 
Buszko J., Nowacki J. 2017. A distributional checklist of the Lepidoptera of Poland. Poznań, Polish Entomological Monographs, 13.

Kalivoda H., Vít'az L., Król W., Pępkowska-Król A., Szewczyk M., Heltai M., Olosutean H., Lyashenko Y., Pavicevic D. 2014. Draft red list of butterflies (Lepidoptera: Papilionoidea) of the Carpathian Mts, in: Carpathian red list of forest habitats and species / Carpathian list of invasive alien species (Draft). Ed. J. Kadlečík. Banská Bystrica, State Nature Conservancy of the Slovak Republic, 200-202.

Kata K. 1999. Nowe stanowiska niektórych rzadkich gatunków motyli (Lepidoptera) w Puszczy Sandomierskiej. Wiad. Entomol. 18, 127-128. [in Polish]

Makomaska-Juchiewicz M. (ed.) 2010. Monitoring gatunków zwierząt - przewodnik metodyczny. Warszawa, GIOŚ. [in Polish]

Mérit X., Manil L. 2016. Contribution à la connaissance de la faune lépidoptérique du val d'Ossola (Piémont, Italie): 6. - Nouvelles localités de Neptis rivularis (Scopoli, 1763) (Lepidoptera: Nymphalidae). Lépidoptères 25, 97-99. [in French]

Nowak S. 2011. Specjalny obszar ochrony siedlisk Lasy Sieniawskie (PLH180054), in: Obszary NATURA 2000 na Podkarpaciu Ed. D. Rogała, A. Marcela. Rzeszów, RDOŚ, 190-195. [in Polish]

Pollard E., Yates T.J. 1993. Monitoring butterflies for ecology and conservation. The British Butterfly Monitoring Scheme. London, Chapman and Hall.

Rozporządzenie Ministra Środowiska z dnia 16 grudnia 2016 r. w sprawie ochrony gatunkowej zwierząt. DzU z 2016 r. poz. 2183 [in Polish]

Sevilleja C.G., Swaay C.A. van, Bourn N., Collins S., Settele J., Warren M.S., Wynhoff I., Roy D.B. 2019. Butterfly Transects Counts: Manual to monitor butterflies. Report VS2019.016. Wageningen, Butterfly Conservation Europe \& De Vlinderstichting/Dutch Butterfly Conservation.

Sielezniew M. 2012. Uwagi ogólne do monitoringu motyli, in: Monitoring gatunków zwierząt. Przewodnik metodyczny. Część IV. Ed. M. Makomaska-Juchiewicz, P. Baran. Warszawa, GIOŚ, 95-105. [in Polish]

Sielezniew M., Dziekańska I. 2010. Fauna Polski. Motyle dzienne. Warszawa, Multico. [in Polish]

Swaay C. van, Cuttelod A., Collins S., Maes D., López Munguira M., Šašić M., Settele J., Verovnik R., Verstrael T., Warren M., Wiemers M., Wynhof I. 2010. European red list of butterfies. Luxembourg, Publications Office of the European Union.

Swaay C.A. van, Nowicki P., Settele J., van Strien A.J. 2008. Butterfly monitoring in Europe: methods, applications and perspectives. Biodivers. Conserv. 17, 3455-3469, https://doi.org/10.1007/s10531008-9491-4.

Warecki A. 2010. Motyle dzienne Polski. Atlas bionomii. Nowy Sącz, Koliber. [in Polish]

WIOŚ. 2003. Raport o stanie środowiska województwa lubelskiego w 2002 roku, http://www.wios.lublin.pl/ wp-content/uploads/srodowisko/raporty-o-stanie-srodowiska/raport-o-stanie-srodowiska-wojlubelskiego-w-2002-r/10.pdf, access: 17.07.2021. [in Polish]

Witkowski Z.J., Król W., Solarz W. (eds.). 2003. Carpathian list of endangered species. WWF and Institute of Nature Conservation. Vienna-Krakow, Polish Academy of Sciences.

Zając A., Zając M. 2001. Atlas rozmieszczenia roślin naczyniowych w Polsce. Kraków, Instytut Botaniki, Uniwersytet Jagielloński. [in Polish]

\section{PROPOZYCJA MONITORINGU GATUNKU NEPTIS RIVULARIS (SCOPOLI, 1763) W POLSCE}

Streszczenie. Pasyn lucylla (Neptis rivularis) jest gatunkiem motyla z rodziny rusałkowatych (Nymphalidae), który w Polsce objęty jest częściową ochroną gatunkową oraz wpisany jest na czerwoną listę zwierząt ginących i zagrożonych w Polsce z kategorią EN. Występowanie i liczebność pasyna lucylli są ściśle zależne od obecności tawuły wierzbolistnej (Spiraea salicifolia L.), która stanowi roślinę żywicielską larw tego gatunku. Ograniczenie zasięgu występowania pasyna lucylli w Polsce wynika także ze spadku liczby odpowiednich siedlisk. W niniejszym artykule przedstawiono propozycję metodyki monitoringu gatunku, opartą na ocenie wskaźników stanu populacji - liczby osobników dorosłych, indeksu liczebności, liczby larw 
i izolacji populacji oraz wskaźników stanu siedliska - występowania tawuły wierzbolistnej i ekspozycji słonecznej mikrosiedlisk. Koncepcję metodyki oceny stanu populacji oparto na bezinwazyjnej obserwacji osobników dorosłych i liczeniu oprzędów gąsienic. Natomiast koncepcja metodyki oceny stanu siedliska oparta jest na silnym związku pasyna lucylli z tawułą wierzbolistną. Proponowane jest coroczne monitorowanie pasyna lucylli na minimum kilkunastu obszarach badawczych w obrębie kraju. Przedstawiona propozycja metodyki monitoringu wymaga przeprowadzenia badań pilotażowych w obrębie znanych stanowisk występowania pasyna lucylli $\mathrm{w}$ celu oceny skuteczności przedstawionych założeń metodyki monitoringu tego gatunku.

Słowa kluczowe: pasyn lucylla, Neptis rivularis, Spiraea salicifolia, monitoring. 
